\title{
FLOCULAÇÃO DE LEVEDURAS POR Lactobacillus fermentum EM PROCESSOS INDUSTRIAIS DE FERMENTAÇÃO ALCOÓLICA AVALIADA POR TÉCNICA FOTOMÉTRICA
}

\author{
Fotometric method to determine yeast flocculation caused by \\ Lactobacillus fermentum in alcoholic fermentation process
}

\author{
Marco Antonio de Castro e Souza ${ }^{1}$, Márcia Justino Rossini Mutton²
}

\begin{abstract}
RESUMO
Na produção de álcool por fermentação com leveduras, a floculação manifesta-se como um mecanismo natural de agregação de células. Essa condição pode ser induzida por vários fatores, entre eles, a interação entre bactérias floculentas como Lactobacillus fermentum e as leveduras. Esse fato torna-se prejudicial para o processo, pois tanto nas unidades que se utilizam do sistema de recuperação de células por centrifugação, como nas que não o utilizam, ocorrem perdas excessivas de fermento, em conseqüência dos problemas operacionais decorrentes da floculação, comprometendo seriamente o desempenho industrial. No presente trabalho, avaliou-se a floculação em vinho proveniente de fermentação experimental, sob duas condições de pH de fermento tratado utilizadas como inóculo e temperaturas de fermentação, não se observando diferenças significativas entre elas. Com este estudo, pôde-se ainda avaliar a capacidade de dispersão dos flocos em três condições de pH no tratamento do fermento em fase industrial, mostrando diferenças altamente significativas entre elas. A maior capacidade de dispersão no tratamento do fermento é desejável para o controle da floculação industrial, permitindo a sua centrifugação, com conseqüente separação das bactérias contaminantes do fermento. Essas constatações tornaram-se possíveis pelo emprego da técnica usual de determinação da floculação por espectrofotometria, modificada pela desfloculação prévia das amostras de vinho e fermento, o que conferiu maior estabilidade nas leituras.
\end{abstract}

Termos para indexação: Bactérias floculentas, dispersão ácida, fermentação experimental, tratamento do fermento, fermento industrial, espectrofotometria.

\begin{abstract}
In the production of alcohol by yeast fermentation, flocculation is a natural mechanism of cell aggregation. This mechanism can be induced by several factors, as the interaction with flocculent bacteria like Lactobacillus fermentum which strongly interacts with yeasts. Flocculation means loss to the process because both the mills that recover cells by centrifugation systems and the mills that do not use this system endure excessive yeast loss, as consequence of operational problems because of the flocculation, being the industrial performance sometimes seriously compromised. The present research evaluated the flocculation in fermented wine under two fermentation temperatures and $\mathrm{pH}$ 's used in treating yeasts, but no statistical difference was found between them. This study also evaluated the dispersion capacity of flakes in three $\mathrm{pH}$ conditions for treating yeasts in the industry stage, showing highly significant differences among such conditions. The highest dispersion capacity in treating yeasts is desirable to control industrial flocculation. These evaluations were possible through the usual technique to determine flocculation, modified by the previous de-flocculation of samples, which was responsible for higher stability in spectrophotometer readings.
\end{abstract}

Index terms: Floculent bacteria, acid dispersion, experimental fermentation, acid treatment, industrial yeast, espectrofotometry.

(Recebido para publicação em 7 de abril de 2003 e aprovado em 14 de julho de 2003)

\section{INTRODUÇÃOO}

$\mathrm{Na}$ floculação, fenômeno que ocorre na fermentação alcoólica por leveduras, as células agrupam-se formando conglomerados de peso muitas vezes superior ao da célula individualizada. Cessada a fase tumultuosa da fermentação, ou quando a agitação mecânica no fermentador é interrompida, esses flocos sedimentam-se rapidamente ou flotam impulsionados por bolhas de gases. A formação de flocos compro-

\footnotetext{
1. Biólogo - Universidade Estadual Paulista, Departamento de Tecnologia, Campus de Jaboticabal - Rua Floriano Peixoto, 1200 - Apt 502 - Centro 14870-810 - Jaboticabal, SP.

2. Engenheira Agrônoma - Universidade Estadual Paulista, Departamento de Tecnologia, Campus de Jaboticabal, mjrmut@fcav.unesp.br
} 
mete a conversão de açúcar em etanol e $\mathrm{CO}_{2}$, pela redução da superfície de contato direto entre as células e o meio. Além disso, nas unidades que se utilizam do reaproveitamento de células, as operações de recuperação de fermento ficam prejudicadas pela presença dessas estruturas (LUDWIG et al., 2001). A floculação pode ser mediada ou incrementada pela presença de pequenas concentrações de íons $\mathrm{Ca}^{2+}$ (STRATFORD, 1993, 1996).

A interação célula-célula, um dos fatores que participam da floculação de leveduras, pode ser controlada primariamente por genes FLO (JAVADEKAR et al., 2000), cujo mecanismo de ação parece estar ligado à ativação de lecitinas de superfície nas células de levedura, responsáveis pela forte ligação à manana $\mathrm{N}$-glicosilada da célula adjacente (JAVADEKAR et al., 2000). A natureza exata dos receptores envolvidos na floculação não está ainda bem elucidada (JAVADEKAR et al., 2000). Aspectos como as modificações estruturais promovidas em proteínas da parede celular das leveduras, pela ação de enzimas proteolíticas, ácidos, álcalis e outros, mostraram certas evidências de sua participação no processo de floculação (CONWAY e KJELLEBERG, 1989; SPEERS et al., 1992).

Além da interação parede-parede das leveduras, atenção tem sido dada à interação leveduras-bactérias. Isso porque, durante a fermentação alcoólica, a contaminação bacteriana promove a formação de flocos, imediatamente após o contato das bactérias com as leveduras (GALLO e CANHOS, 1991; YOKOYA e OLIVA NETO, 1991; YOKOYA, 1991; ZARATTINI et al., 1993; LUDWIG et al., 1995; GUERRA e ANGELIS, 1998). Bactérias, como Sporolactobacillus e Lactobacillus, foram descritas como os agentes causadores da floculação (YOKOYA, 1991; ZARATTINI et al., 1993). O isolamento freqüente de cepas de $L$. fermentum em fermentações floculadas evidenciou sua importância como contaminante de processos industriais (YOKOYA e OLIVA NETO, 1991; ZARATTINI et al., 1993; GUERRA e ANGELIS, 1998).

Ao término do processo fermentativo, o vinho passa pelo processo de centrifugação. Nesse, originamse dois produtos: o vinho delevedurado, que é destinado à destilação, e o leite ou creme de leveduras, constituído por células de leveduras (inóculo), além de outras leveduras e bactérias contaminantes. Após diluição e acidificação, o leite de levedura é reciclado no processo. Esse tratamento ácido é pratica comum para o controle de bactérias contaminantes contidas no leite. Gallo e Canhos (1991) observaram a redução de $44,3 \%$ da micro- biota contaminante, em função do vigor e tempo desse tratamento. Entretanto, o tratamento ácido da levedura, quando floculada, induz a dispersão do fermento e das bactérias, mas não a sua total eliminação (GUERRA e ANGELIS, 1998).

Floculações experimentais demonstraram haver faixas de dispersão entre as células de leveduras e bactérias, decorrentes da alteração de valores de $\mathrm{pH}$. Essas encontram-se em valores inferiores a 2,5 e acima de 12 (YOKOYA e OLIVA NETO, 1991). A força de ligação molecular nesse tipo de floculação é muito forte, e somente pode ser efetivamente rompida em $\mathrm{pH}$ abaixo de 2,0. Entretanto, a ligação pode ser restabelecida imediatamente, com a elevação do pH.

Os flocos formados sedimentam-se rapidamente, resultando em duas fases, uma concentrada, rica em flocos maiores, e outra mais dispersa, contendo poucos flocos menores e células isoladas de levedura. Os flocos podem ser analisados sob três aspectos: número de células, tamanho e estabilidade quanto ao rompimento das ligações. Durante a floculação, Woof (1962) observou dois fenômenos que ocorrem simultaneamente: a floculação propriamente dita e a sedimentação dos flocos, mas que são completamente independentes entre si.

$\mathrm{Na}$ ausência de uma metodologia própria, ideal para medir floculação, a "American Society of Brewing Chemistry" (ASBC) adotou o "Teste de Helm", com certas modificações, como "padrão". Esse procedimento utiliza células de levedura recuperadas por centrifugação que, após lavagem, são ressuspendidas e submetidas à leitura espectrofotométrica, a $620 \mathrm{~nm}$ (SOARES e MOTA, 1997).

Para avaliar a floculação de leveduras induzidas por bactérias, Ludwig et al. (2001) inocularam bactérias encontradas nas unidades de fermentação das destilarias que, após isolamento e crescimento em meios de cultura apropriados, eram adicionadas às suspensões de leveduras. A floculação era estimada, à semelhança da turbidimetria, a $600 \mathrm{~nm}$.

Com o presente estudo, objetivou-se avaliar características de floculação de leveduras em laboratório, induzida por Lactobacillus fermentum, em duas condições de temperatura de fermentação e dois valores de $\mathrm{pH}$ de tratamento ácido. Estudou-se também o comportamento da floculação na indústria sob três condições de $\mathrm{pH}$ no tratamento ácido, uma vez que a separadora centrífuga age como eliminadora de bactérias por densidade. A desagregação dos flocos torna-se uma condição favorável no controle da floculação industrial,

Ciênc. agrotec., Lavras, v. 28, n. 4, p. 893-898, jul./ago., 2004 
quando se adota a centrifugação do fermento tratado, pois, estando isoladas, podem ser separadas no vinho delevedurado.

\section{MATERIAL E MÉTODOS}

O experimento foi conduzido em duas etapas, observando-se na primeira o comportamento de floculação induzida em fermentação, sob condições controladas em laboratório. Nessa etapa, foram testadas duas condições de temperatura de fermentação $\left(32\right.$ e $\left.38^{\circ} \mathrm{C}\right)$ e dois diferentes valores de $\mathrm{pH}$ no tratamento do fermento $(2,0$ e 3,0$)$. Essas fermentações foram preparadas em oito períodos diferentes durante a safra 2000/2001 em Usina de Açúcar e Álcool da região de Ribeirão Preto S.P. Na segunda etapa, pôde-se avaliar na mesma safra as condições de floculação em vinho e fermento tratado, obtidos diretamente na indústria, nas fases de produção.

\section{Fermentações experimentais com floculação induzida}

\section{Preparação do inóculo}

Iniciou-se a preparação a partir da bactéria liofilizada, Lactobacillus fermentum CCT-1405 (floculenta), obtida na Fundação Tropical de Pesquisas e Tecnologia 'André Tosello. O crescimento foi efetuado em meio caldo MRS(Merck ref.10.661), esterilizado a $121^{\circ} \mathrm{C}$ por 15 minutos. Tubos inoculados, com 24 horas de incubação a $33^{\circ} \mathrm{C}$, foram transferidos seqüencialmente em volumes crescentes, múltiplos de 10 , até o volume final de $1100 \mathrm{~mL}$, em erlenmeyers de 2000 $\mathrm{mL}$, incubado por 48 horas. Após crescimento, as bactérias foram recuperadas por ultra-centrifugação a $13.000 \mathrm{~g}$ por 8 minutos a $4^{\circ} \mathrm{C}$, sendo o pellet suspenso em tampão citrato $5 \mathrm{mM}$ + EDTA $5 \mathrm{mM}$ a pH 3.0, ajustando-se a concentração de células para $10^{13}$ células/mL, mediante contagem em câmara de PetroffHausser. Essa suspensão foi armazenada a $8^{\circ} \mathrm{C}$ até o momento da utilização.

\section{Preparação da fermentação}

As fermentações foram conduzidas em frascos erlenmeyers de $2000 \mathrm{~mL}$, contendo $300 \mathrm{~mL}$ de fermento tratado e $700 \mathrm{~mL}$ de mosto, garantindo concentrações de $10^{8}$ células de leveduras por mL. O mosto, cuja constituição consistia em caldo misto, mel final e água, em proporções definidas pelas condições de processo vigentes no período, foi coletado diretamente na indús- tria. O fermento foi preparado com o leite de levedura com concentração de $60 \%$ de células, obtido diretamente das separadoras centrífuga em operação. Com o leite de levedura obtido, foram feitas diluições com água até a redução da concentração para $30 \%$. Utilizou-se para diluição água de manancial superficial, que continha água residual da lavagem de $\mathrm{CO}_{2}$. O fermento diluído foi submetido, então, ao tratamento ácido com $\mathrm{H}_{2} \mathrm{SO}_{4} 98 \%$ de pureza, em condições de pH 2.0 e 3.0. A fermentação foi contaminada imediatamente após o preparo com $10 \mathrm{~mL}$ da suspensão bacteriana em citrato de sódio. Os frascos foram agitados com movimentos circulares, vigorosamente para homogeneização do inóculo. As fermentações preparadas em duplicata foram incubadas em estufas de cultura com temperaturas de 32 e $38^{\circ} \mathrm{C}$ até a cessação da evolução de gás, considerando-se assim o término da fermentação. Coletaram-se amostras do início, meio e final das fermentações, imediatamente após a agitação, transferindo-se volumes de $40 \mathrm{~mL}$ para tubos com fundo redondo de $80 \mathrm{~mL}$. Essas amostras foram, então, submetidas à determinação da taxa de floculação.

\section{Floculação em fermentação industrial: Tra- tamento Ácido}

$\mathrm{Na}$ segunda etapa do estudo, foram coletadas amostras de fermento tratado das cubas de tratamento. Essas foram submetidas à determinação de taxas de floculação da mesma forma que as das fermentações experimentais.

Para se avaliar o efeito da acidez, coletaramse oito amostras de fermento tratado na indústria em fase intensamente floculada, diluído com água na proporção de $1: 1$ e acidificados $\left(\mathrm{H}_{2} \mathrm{SO}_{4}\right.$ técnico $)$ até valores de $\mathrm{pH} 2,5 ; 2,3$ e 2,1 . As amostras foram então analisadas.

Obteve-se a Taxa de Sedimentação Diferencial (TSD), utilizada na avaliação do tamanho dos flocos em função do tempo de sedimentação, dividindo-se a variação observada nos valores de absorvância de cada um dos tratamentos com diferentes valores de $\mathrm{pH}$, pelo tempo de sedimentação (5 min.).

\section{Determinação da Taxa de Floculação}

Dos materiais coletados das fermentações experimentais e da indústria, foram retiradas duas alíquotas de 5,0 mL com auxílio de pipeta a $0,5 \mathrm{~cm}$ de profundidade a partir da superfície do líquido. A primeira foi re- 
tirada após agitação do tubo por inversão, designada como tempo zero e, após cinco minutos de repouso, retirou-se a segunda. Essas alíquotas foram transferidas para tubos de ensaio com tampa rosqueável, contendo $0,5 \mathrm{~mL}$ de $\mathrm{H}_{2} \mathrm{SO}_{4}$ a $20 \%$, e agitadas por inversão. Após esse procedimento, que promoveu a desfloculação total das amostras, determinou-se o valor de absorbância dessas em espectrofotômetro ajustado a $600 \mathrm{~nm}$. Obtidos esses valores, utilizou-se da fórmula a seguir para a determinação das taxas de floculação: $\mathrm{TF}=(\mathrm{Ai} / \mathrm{Af}) \mathrm{x}$ 100, em que $A i$ corresponde à leitura de absorvância das amostras no tempo zero e $A f$ após 5 min.

\section{Análise Estatística}

Os resultados das fermentações experimentais com variação de temperatura e $\mathrm{pH}$ no tratamento do fermento foram analisados como um experimento fatorial $2 \times 2$ com oito repetições com dois fatores, $\mathrm{pH}$ e temperatura.

Analisaram-se pelo programa STAT a variância para o parâmetro floculação em diferentes fases da fermentação e também o efeito de três condições de $\mathrm{pH}$ no tratamento industrial.

\section{RESULTADOS E DISCUSSÃO}

Os resultados obtidos nos testes de floculação do fermento industrial por Lactobacillus fermentum são apresentados na Figura1. A análise fatorial demonstrou não haver diferenças significativas para taxa de floculação entre os valores de $\mathrm{pH}$ do tratamento do fermento e também as temperaturas adotadas.

Na Tabela 1, são apresentados os valores obtidos para taxa de floculação nos três períodos de fermentação (início, meio e fim), não se observando pela análise de variância alterações significativas entre eles.

De acordo com Wilcocks e Smart (1995), a ação do tratamento ácido pode retirar fosfatos das células de leveduras em proporções correspondentes ao vigor do pH e do tempo utilizado. Entretanto, a introdução dessas leveduras em meios ricos em sais, como fósforo e potássio, repolariza a superfície da parede celular, deixando-a apta à nova floculação (YOKOYA e OLIVA NETO, 1991). Esse fato corrobora com o comportameto observado nas análises de variância para os testes de fermentação, sugerindo que os valores de $\mathrm{pH}$ utilizados no tratamento do fermento não influenciaram a floculação.

Os valores de desvio-padrão e variância, para as taxas de sedimentação diferencial, calculados para o tratamento $\mathrm{pH} 2,1$, foram 0,0253 e 0,00064 ; para $\mathrm{pH} 2,3,0,0227$ e 0,00051 e para o $\mathrm{pH} 2,5,0,0219$ e 0,00049 , não apresentando discrepâncias entre valores.

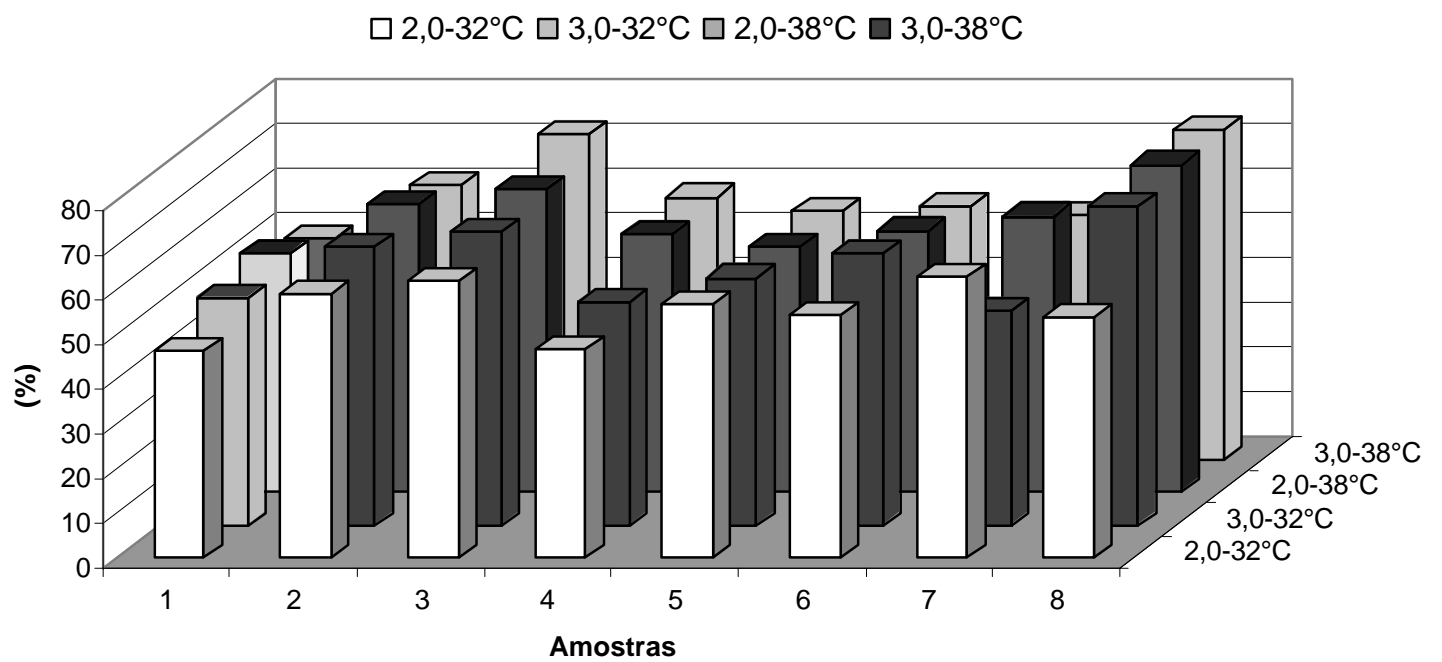

FIGURA 1 - Taxas de floculação em fermentação induzida por Lactobacillus fermentum CCT-1405 com variação nas temperaturas de fermentação e pH de tratamento ácido do fermento.

Ciênc. agrotec., Lavras, v. 28, n. 4, p. 893-898, jul./ago., 2004 
Na Figura 2 são apresentados os resultados do efeito dos diferentes valores de $\mathrm{pH}$ sobre o fermento, evidenciando um comportamento decrescente nas Taxas de Sedimentação Diferencial (TSD), possivelmente pela redução do tamanho dos flocos e conseqüente diminuição da sedimentação dessas estruturas, como também foi observado por Woof (1962).

Esses índices de TSD, quando se observa a ordem decrescente de valores de $\mathrm{pH}$, são inversamente proporcionais às taxas de floculação, parecendo indicar que as duas taxas determinadas são complementares, fornecendo informações em relação à intensidade da floculação como também em relação à velocidade de sedimentação dos flocos. As variações entre os valores da TSD, nos diferentes tratamentos, significam que nessas amostras existiam flocos de tamanhos diferentes e tempos de sedimentação próprios.
De acordo com Amory et al. (1988), o melhor método para medir floculação seria a medida direta da sua taxa; entretanto, isso é difícil em virtude de ocorrerem os dois fenômenos em conjunto, floculação e sedimentação. Isso pode ser justificado pela maior velocidade de sedimentação dos grandes agrupamentos de leveduras, presentes nas amostras, ocasionando instabilidade nas leituras. Comportamento semelhante foi observado por Davis e Hunt (1986) nos testes de floculação realizados com cepa de Saccharomyces cerevisiae ATCC 46785, de média floculência, durante leitura espectrofotométrica a $632 \mathrm{~nm}$. Constatou-se pela análise de curvas de sedimentação de leveduras de cervejaria, sob efeito da floculação, que esse fenômeno é governado pela distribuição do tamanho dos flocos em suspensão (WOOF, 1962).

TABELA 1 - Taxas de floculação em três períodos de fermentação induzida por L. fermentum CCT-1405.

\begin{tabular}{ccccccccc}
\hline & $\mathbf{1}$ & $\mathbf{2}$ & $\mathbf{3}$ & $\mathbf{4}$ & $\mathbf{5}$ & $\mathbf{6}$ & $\mathbf{7}$ & $\mathbf{8}$ \\
\cline { 2 - 9 } INÍCIO & 50,65 & 64,96 & 68,08 & 60,34 & 53,58 & 52,19 & 61,85 & 65,55 \\
MEIO & 54,08 & 61,58 & 68,45 & 48,47 & 52,24 & 67,84 & 51,05 & 51,65 \\
FIM & 45,18 & 58,54 & 64,38 & 50,94 & 61,24 & 52,26 & 57,56 & 86,96 \\
\hline
\end{tabular}

$F=5,85^{\star x}$

\section{Taxa Floc $\square$ Variação abs. $\square$ Absorv.difer $\square$ Tempo sedim.}

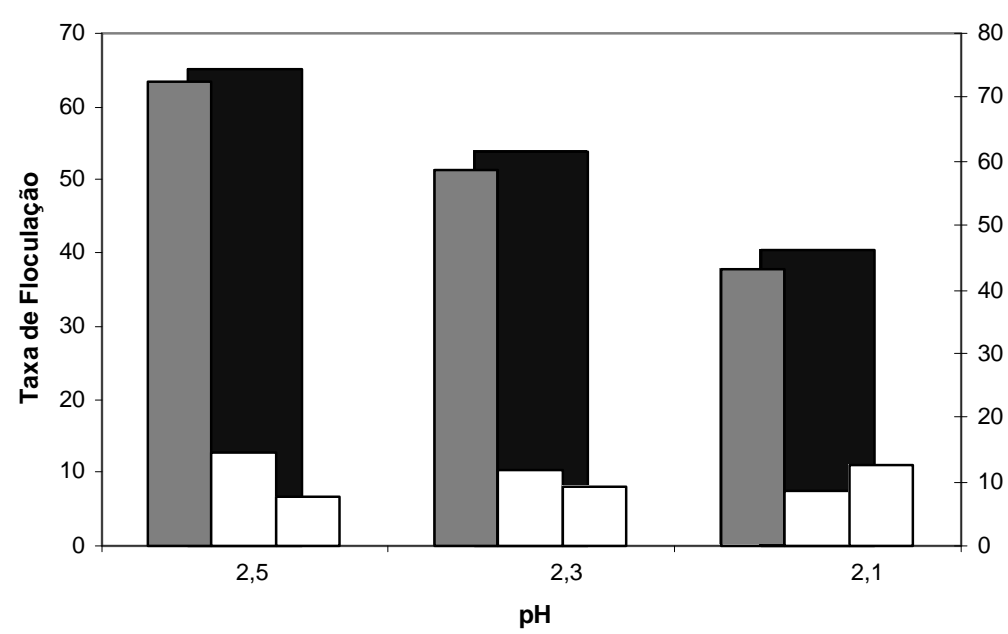

FIGURA 2 - Taxas de floculação de leveduras, valores de absorvância e tempos de sedimentação em três condições de $\mathrm{pH}$ de tratamento de fermento. 


\section{CONCLUSÕES}

O tratamento ácido do fermento promove a dispersão dos flocos de acordo com o vigor do $\mathrm{pH}$ utilizado, possibilitando a homogeneização de bactérias e leveduras.

O procedimento analítico adaptado para determinar as taxas de floculação mostrou não depender das concentrações de leveduras e bactérias contidas no meio fermentado, uma vez que os flocos são totalmente dispersados. Isso torna os resultados obtidos característicos de uma suspensão mais homogênea contendo poucas células agrupadas e muitas individualizadas. A redução brusca do $\mathrm{pH}$ dispersou as células de leveduras e bactérias, prolongando o tempo de sedimentação, conferindo, assim, uma maior estabilidade nas leituras de densidade ótica, tornando-o mais adequado para utilização nas indústrias de produção de álcool.

\section{REFERÊNCIAS BIBLIOGRÁFICAS}

AMORY, D. E.; DUFOUR, J. P.; ROUXHET, P. G. Flocculence of brewery yeasts and their surface properties: chemical composition, electrostatic charge and hydrofobicity. Journal of Institute of Brewing, London, v. 94, p. 79-84, 1988.

CONWAY, P. L.; KJELLEBERG, S. Protein-mediated adhesion of lactobacillus fermentum strain 737 to mouse stomach squamous epithelium. Journal of General Microbiology, London, v. 135, p. 1175-1186, 1989.

DAVIS, R. H.; HUNT, T. P. Modeling and measurement of yeast flocculation. Biotechnology Progress, New York, v. 2, n. 2, p. 91-97, 1986.

GALLO, C. R.; CANHOS, V. P. Efeito do tratamento ácido no fermento sobre a microbiota bacteriana contaminante da fermentação alcoólica. Stab: Açúcar, Álcool e Subprodutos, Piracicaba, v. 9, n. 6, p. 35-37, jul./ago. 1991.

GUERRA, E. J.; ANGELIS, D. F. Floculação da levedura induzida por bactérias na fermentação etanólica: I. método de detecção preventiva e estudos para o controle. Stab: Açúcar, Álcool e Subprodutos, Piracicaba, v. 16, n. 6, p. 25-27, jul./ago. 1998.

JAVADEKAR, V. S.; SIVARAMAN, S. R.; SAINKAR, S. R.; KHAN, M. I. A mannose-binding protein from de cell surface of flocculent Saccharomyces cerevisiae (NCIM 3528): its role in flocculation. Yeast, Davis, v. 16, p. 99-110, 2000.
LUDWIG, K. M.; OLIVA NETO, P.; ANGELIS, D. F. Desenvolvimento de uma técnica para monitoramento industrial da floculação do fermento por bactérias floculentas em destilarias produtoras de etanol. In: SIMPÓSIO NACIONAL DE FERMENTAÇÃO, 11., 1995, São Carlos. Anais... São Carlos: UFSCAR, 1995. p. 7-12.

LUDWIG, K. M.; OLIVA NETO, P.; ANGELIS, D. F. Quantificação da floculação de Saccharomyces cerevisiae por bactérias contaminantes da fermentação alcoólica. Ciência e Tecnologia de Alimentos, Campinas, v. 21, n. 1, p. 63-68, jan./abr. 2001.

SOARES, E. V.; MOTA, E. M. Quantification of yeast flocculation. Journal of the Institute of Brewing, London, v. 103, p. 93-98, 1997.

SPEERS, A.; TUNG, M. A.; DURANCE, T. D.; STEWART, G. G. Biochemical aspects of yeast flocculation and its measurement: a review. Journal of the Institute of Brewing, London, v. 98, p. 293-300, 1992.

STRATFORD, M. Yeast flocculation: flocculation onset and receptor availability, Yeast, Davis, v. 9, n. 85 p. 94, 1993.

STRATFORD, M. Yeast flocculation: restructuring the theories in line with recent research. Cerevisa and Biotechnology, [S.1.], v. 21, n. 1, p. 38-45, 1996.

WILCOCKS, K. L.; SMART, K. A. The impoirtance of surface charge and hydrophobicity for the flocculation of chain-forming brewing yeast strains and resistence of these parameters to acid washing. FEMS Microbiology Letters, Amsterdam, v. 134, p. 293-297, 1995.

WOOF, J. B. An approach to yeast sedimentation characteristics. Journal of the Institute of Brewing, London, v. 68, p. 315-317, 1962.

YOKOYA, F. Problemas com contaminantes na fermentação alcoólica. Stab: Açúcar Álcool e Subprodutos, Piracicaba, v. 9, n. 6, p. 38-39, jul./ago. 1991.

YOKOYA, F.; OLIVA NETO, P. Características da floculação de leveduras por Lactobacillus fermentum. Revista de Microbiologia, São Paulo, v. 22, n. 1, p. 12-16, 1991.

ZARATTINI, R. A.; WILLIAMS, J. W.; ERNANDES, J. R.; STEWART, G. G. Bacterial induced flocculation in selected brewing strains of Saccharomyces. Cerevisa and Biotechnology, [S.1.], v. 18, n. 4, p. 65-75, 1993. 